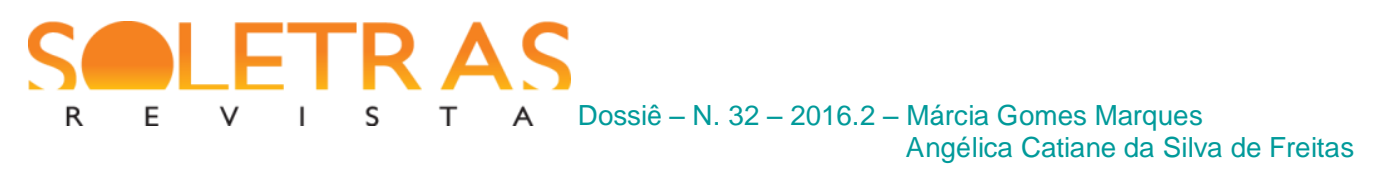

\title{
Do romance ao filme: transferência e tradução na adaptação Dom
}

\author{
Márcia Gomes Marques ${ }^{1}$ \\ Angélica Catiane da Silva de Freitas ${ }^{2}$ \\ Universidade Federal de Mato Grosso do Sul
}

\begin{abstract}
Resumo: Este trabalho tem como objetivo discutir acerca da adaptação da literatura para o audiovisual, desde seus aspectos de transferência e de tradução de elementos de um suporte para outro, considerando obras com diferentes linguagens e o deslocamento de contexto histórico-social de produção na reproposição temática. Com esse fim, analisa-se o filme Dom, de Moacyr Góes, produzido em 2003, aproximadamente um século após a escritura do romance Dom Casmurro, de Machado de Assis, no qual foi inspirado. Verificam-se, nesse caso, as alterações relativas às ações, aos acontecimentos e à composição dos personagens da narrativa na construção da obra derivada. Identifica-se, então, a transposição entre lógicas de produção e consumo diversas, pois o texto derivado aproveita o anterior e o repropõe desde os formatos industriais da cultura midiática, levando em consideração as expectativas do público na recomposição temática do texto-fonte. Para tanto, enxuga aspectos da história, focalizando na última parte do romance, e recompõe o final, que passa a ser marcado pela superação dos problemas e pelo compromisso perseverante com a felicidade.
\end{abstract}

Palavras-chave: Audiovisual. Tradução. Narrativa.

\section{Introdução}

Sempre que uma nova forma de comunicação surge, começa a haver o receio de que ela suplante as formas de comunicação anteriores. O universo literário há muito tem sentido sua história ameaçada pela forte presença social dos suportes audiovisuais, como a televisão e o cinema. Não obstante, o que se verifica na atualidade é um diálogo intenso entre textos de diferentes linguagens, suportes e gêneros. Transformar obras literárias em narrativas visuais, por exemplo, é uma prática que remonta ao surgimento do próprio cinema e tem se acentuado de tal forma que, hoje, grande parte dos filmes conta com argumentos já escritos anteriormente, em vez de recorrer a um roteiro original.

\footnotetext{
${ }^{1}$ Doutora em Ciências Sociais pela Pontifícia Università Gregoriana, Roma, é professora do Curso de Comunicação e do Mestrado em Estudos de Linguagens da Universidade Federal de Mato Grosso do Sul. Socióloga, formada pela PUC do Rio de Janeiro, e mestre em Comunicación Social pela Pontifícia Universidad Javeriana - Bogotá. Possui trabalhos publicados nas áreas de Audiovisual e Estudos de Recepção. E-mail: marciagm@yahoo.com

${ }^{2}$ Doutoranda em Letras, Teoria Literária, pelo PPG- Doutorado em Letras da Universidade Federal de Mato Grosso do Sul (UFMS). Mestre em Teoria Literária e Estudos Comparados pelo PPG Mestrado em Estudos de Linguagens da mesma universidade. Licenciada em Letras Português/ Inglês, também pela UFMS. Bolsista de Mestrado e Doutorado pela CAPES. E-mail: catianedefreitas@yahoo.com.br
}

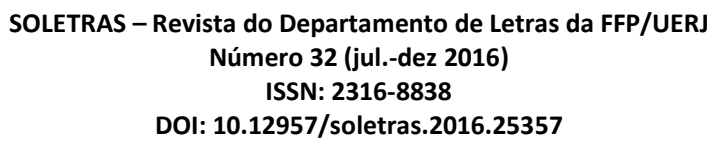


Sabendo que o diálogo entre as diversas mídias tem sido intenso, principalmente no que tange à adaptação de textos da linguagem escrita para a audiovisual, algumas questões começam a surgir, como, por exemplo: quais são os motivos que impulsionam esse tipo de criação artística? Ou, ainda: o que faz com que as pessoas se comprazam em assistir à refacção de uma obra já conhecida? Segundo John Ellis (1982, p. 4-5), citado por Sanders (2008, p. 24), assistimos à adaptação de uma obra porque buscamos repetir, ou prolongar, uma experiência prazerosa anterior. E de que modo a afirmação de Ellis continuaria a ser válida, nos casos - sempre mais frequentes - em que o contato primeiro se dá com os textos da linguagem audiovisual, que acabam por atingir um público muito maior do que aquele que possui acesso à cultura livresca?

O cenário de distribuição e acesso à produção cultural atual não impõe uma ordem cronológica de contato com os textos, dos mais antigos ou dos textos-fonte para os atuais ou derivados. Enquanto, tradicionalmente, os estudos de adaptação se ativeram principalmente nas chamadas obras de autor, derivadas de outras obras de autor, do teatro e da literatura para o cinema, por exemplo, a produção cultural atual está marcada pelo aproveitamento de obras de uma variedade de tipos, ligadas à cultura erudita ou não, para produtos midiáticos que têm como escopo chegar ao grande público.

Um aspecto essencial, nesse sentido, é que a lógica de produção atual combina formatos industriais com outros tipos de textos, realizados desde outras lógicas (MARTÍN BARBERO, 2003) e pensados para outros perfis de público. É importante que os estudos acadêmicos se debrucem sobre essa lógica de produção e consumo cultural, composta por uma mistura de temporalidades, de formatos industriais, de tecnicidades e textos-fonte de origens diversas. Pode-se dizer que o tipo de público previsto por essas obras, aliado a essa mistura de diversos tipos de influências, marcam a oferta cultural do momento, e é necessário que os estudos acadêmicos procurem entender mais e melhor acerca da lógica que orienta a produção e o consumo dessas obras (JENSEN, 2014).

No que tange à transposição de textos entre suportes e no caso específico do livro para a tela, uma questão contra a qual têm arrazoado alguns teóricos da adaptação, como Robert Stam, Linda Hutcheon, entre outros, é a tendência a superestimar o texto escrito em detrimento do texto visual. Segundo Stam (2006), o palavreado utilizado pela crítica sobre as adaptações é comumente moralista e acaba por sugerir que o cinema tem prestado um 
“desserviço à Literatura", propondo obras que não estão à altura dos textos-fontes nos quais se inspiram.

Está claro que sim, existem adaptações pouco interessantes ou de qualidade estética duvidosa de romances importantes da literatura mundial, ainda que nem sempre seja assim. Mas a questão que mais incomoda alguns teóricos da adaptação é o fato de a fidelidade ter sido utilizada como um princípio metodológico para o estudo das adaptações (STAM, 2008). Entre outras coisas, esse tipo de abordagem desconsidera o papel do autor da obra que se cria a partir do texto literário, bem como o seu horizonte de experiências (JAUSS, 1987), social e historicamente contextualizado, além de negar "a própria natureza do texto literário, que é a possibilidade de suscitar interpretações diversas e ganhar novos sentidos com o passar do tempo e a mudança das circunstâncias" (GUIMARÃES, 2003, p. 95).

Partindo do pressuposto de que cada linguagem, gênero e suporte possuem especificidades, assim como o momento e o lugar social em que a obra é produzida ou relida interferem no conteúdo e na forma do texto que está em transcodificação, este trabalho busca refletir sobre os mecanismos utilizados pelas mídias audiovisuais, para expor e atualizar os conteúdos e histórias adaptados da literatura, nesse caso específico, o filme Dom, de Moacyr Góes, adaptação cinematográfica do romance Dom Casmurro, de Machado de Assis. Para tanto, partimos da concepção da adaptação como tradução, como proposta por Brian McFarlane (1996).

Ao comparar a obra do suporte cinematográfico com o texto-fonte do suporte livro, consideram-se, adicionalmente, o contexto e algumas das características peculiares das obras em questão.

\section{Adaptação, tradução e texto derivado}

Embora a autonomia da adaptação em relação ao texto-fonte seja algo indiscutível, a questão subsiste e deve ser questionada, pois há uma implicada suposição, segundo Linda Hutcheon (2011), de que o objetivo dos adaptadores seja simplesmente o de reproduzir os textos que adaptam. A autora defende que as adaptações são repetição sem replicação e que podem surgir de diferentes intenções em relação ao texto de origem, como "apagar a lembrança do texto adaptado", homenageá-lo, ou "prestar uma homenagem contestadora" 
(ibidem, p. 27-28). Hutcheon define a adaptação como um trabalho inerentemente palimpsestuoso:

Se conhecemos o texto anterior, sentiremos constantemente sua presença pairando sobre aquele que estamos experienciando diretamente. Quando dizemos que uma obra é adaptação, anunciamos abertamente sua relação declarada com outra(s) obra(s). É isso o que Gérard Genette (1982:5) entende por um texto em "segundo grau", criado e então recebido em relação a um texto anterior (HUTCHEON, 2011, p. 27).

A adaptação implica, então, um ato (anterior) de recepção e que se estende por toda a criação do texto derivado. Mas o adaptador, como sujeito social que é, usa o texto-fonte desde a posição no tempo e espaço que ocupa, ou seja, desde sua perspectiva histórico-social e de acordo com seus interesses e inquietações.

A obra adaptada lida com a instância da recepção de várias maneiras. O seu autor é receptor do texto de partida e mescla, em sua feitura, momentos de autoria e coautoria, além de combinar sua experiência direta do texto com aquela indireta: as impressões socialmente compartilhadas sobre a obra e acerca de seu percurso histórico-literário. O trabalho produzido traz consigo o seu receptor, modelo e empírico e lida ainda com o receptor implicado na obra original, com as estratégias utilizadas para envolvê-lo e solicitar a sua cooperação textual. Sobre os elementos constitutivos do texto e de seus vínculos com seu público, Claus Clüver afirma que:

Um esforço acadêmico para entender nossos hábitos de leitura (isto é, o modo como atribuímos sentido a textos) deverá atentar para os tipos de relações intertextuais que costumamos estabelecer [...] No caso de textos produzidos para públicos distantes de nós no tempo, no espaço ou pela cultura (incluídas aí as subculturas contemporâneas), deveremos tentar reconstruir os códigos e convenções que governam as práticas interpretativas daquele público- ao menos se estivermos interessados em saber o que um texto pode ter significado ou o que se desejava que ele significasse então (CLÜVER, 1997, p. 40-1).

A compreensão das especificidades de códigos e convenções é importante na análise da adaptação aqui estudada, visto que o filme de Góes é ambientado a um século de distância de seu texto-fonte, o romance Dom Casmurro. Segundo os autores da estética da recepção, como Jauss (1987), cada leitor possui, no ato de leitura, seu próprio horizonte de experiências 
que precede a leitura do texto. Então, no caso de termos diferentes momentos temporais, esses horizontes serão também distintos, ou ainda, como afirma Heidrun Olinto:

O texto fora do contexto em que foi produzido perde suas características, gerando um outro texto. $\mathrm{O}$ produto dessa transfiguração exige também uma mudança no modo de leitura, visto que a nova situação comunicativa redimensiona as condições de produção e recepção (OLINTO, 1995 apud NAGAMINI, 2004, p. 36).

Neste trabalho, tomamos como parâmetro para a reflexão do filme Dom a noção de adaptação como um processo tradução, conforme proposto por Brian McFarlane (1996), um dos pioneiros nas novas abordagens para o estudo de adaptações. Segundo Taïs Nogueira Flores Diniz (2005, p. 19), essa forma de compreender as adaptações veio a ser uma das mais recorrentes nos estudos atuais e consiste em procurar equivalências e correspondências entre os dois sistemas semióticos, o do texto-fonte e o da adaptação cinematográfica.

McFarlane diferencia a história contada de seu enredo, ou seja, da forma específica com que a história é contada a cada vez. De acordo com esse autor, enquanto a história pode ser traduzida com certa facilidade, o enredo requer ações adaptativas a cada vez que é reproposto. Adicionalmente, desde as contribuições de autores como Barthes (1966) e Chatman (1978), McFarlane destaca dois eixos analíticos fundamentais a serem considerados para o entendimento dos textos adaptados: por um lado, o conjunto de ações, eventos e acontecimentos a partir dos quais uma história é construída (funções distribucionais), que se apresentam de forma horizontal na construção narrativa; por outro lado, os aspectos psicológicos e de atmosfera referentes à caracterização e aos atributos dos personagens e dos lugares da representação (funções integracionais), que se dão de forma vertical na construção narrativa e na relação que os leitores têm com as obras.

Para McFarlane, a enorme e durável popularidade do cinema se deve ao que ele tem em comum também com o romance, isto é, a sua capacidade de narrar. Para ele, os aspectos mais importantes de serem transferidos são os que se referem às ações e eventos da narrativa: como não dependem da linguagem, podem ser mais facilmente transferidos de um meio/suporte a outro. No que se refere às funções integracionais, enquanto que os nomes, as profissões e os detalhes da configuração física dos personagens são mais facilmente transplantados de uma linguagem para outra, os referentes à atmosfera e aos aspectos psicológicos exigem mecanismos de transferência mais complexos, pois dependem, entre 
outra coisa, de serem atuados, transformados em performance, ou ainda, dos recursos expressivos próprios do audiovisual, como enquadramentos, iluminação, cenário, etc.

\section{Do livro ao cinema: as ações, os eventos e os atributos transferidos e "ajustados"}

O livro inicia com o narrador explicando o porquê de ter escolhido para seu texto o título de Dom Casmurro, dizendo que fora apelidado dessa forma por um poeta do trem, e que a alcunha tinha por objetivo designar seus hábitos de homem calado e metido consigo, sendo que, "Dom" veio por ironia, para atribuir-lhe ares de fidalgo. No segundo capítulo, ele conta os motivos que o levam à escritura do livro: "atar as duas pontas da vida, restaurar na velhice a adolescência" (ASSIS, 1997, p. 1-2). A partir daí, começa a reconstituir a história de como seu romance com Capitu, sua vizinha, iniciou ainda na adolescência de ambos, "instigado" pela denúncia de José Dias, agregado há anos em sua casa, que lembrara à mãe de Bentinho da antiga promessa que havia feito de mandá-lo para o seminário, acrescentando que a nobre senhora deveria apressar-se para não correr o risco de os dois adolescentes "pegarem de namoro". Bentinho acaba tendo que ir para o seminário contra sua vontade, e lá conhece Escobar, que se torna seu melhor amigo.

Capitu, inconformada com a separação entre ela e Bentinho, tenta encontrar maneiras para reverter a situação, como convencer o próprio José Dias a voltar atrás nos conselhos que dera à Dona Glória e dissuadi-la da ideia de tornar Bentinho um padre. Contudo, quem acaba encontrando uma solução para o problema é Escobar, o amigo seminarista, que sugere a Bentinho pedir a sua mãe para cumprir a promessa de outra forma, oferecendo ao altar um padre que não seja ele, mas um órfão, por exemplo. E foi o que se fez. Combinaram ainda de sair juntos do seminário, uma vez que Escobar também não desejava ser padre, mas comerciante. Bentinho deixou o seminário aos 17 anos e foi estudar direito, voltando bacharel cinco anos depois.

$\mathrm{Na}$ volta para casa, Bentinho fica sabendo por José Dias que todos já desconfiam de seu interesse por Capitu e que o aprovam. Desta vez, o agregado lhe elogia inúmeras qualidades da moça. O narrador-personagem conta ainda que Escobar, estabelecendo relações comerciais com o pai de Sancha, melhor amiga de Capitu, acabou casando com a filha e, também, que o amigo foi o "terceiro" na troca de cartas entre ele e Capitu, enquanto ambos estavam distantes um do outro. 
Daí em diante, o narrador resume ao máximo a história. Até aqui temos 157 páginas do livro, ao passo que, daqui para o final, só restarão mais 60. Da conversa com José Dias, o narrador dá um salto para a sua "lua-de-mel" na Tijuca. A partir deste momento, ele narra os primeiros anos de casados; os ciúmes que tinha da esposa, a amizade próxima entre eles e o casal Escobar e Sancha; a necessidade que surge de ter um filho; o nascimento de Ezequiel; o surgimento da dúvida relacionada às semelhanças entre Ezequiel e Escobar; a morte do amigo no mar, e a crescente desconfiança que o atormenta em relação à fidelidade de Capitu.

Finalmente, o desfecho trágico, que é a separação de ambos, quando Bentinho decide que Capitu irá para a Europa com o filho, embora, frente à sociedade continue mantendo as aparências. Temos ainda a volta de Ezequiel, já moço, da Europa, e a indiferença do pai em relação a ele. Sem ter alternativa, Bentinho fica com o filho por um tempo, mas sente um grande alívio quando este sai em uma viagem de estudos pela Grécia, Egito e Palestina, e um alívio ainda maior quando sabe de sua morte nas mediações de Jerusalém. Ao chegar ao fim de sua narrativa, o narrador-personagem conclui que realmente não há dúvidas de que foi traído pela sua mulher e o seu melhor amigo.

No filme Dom (2003), a primeira cena é um acidente de trânsito nos dias atuais, em uma grande metrópole, na qual aparece o protagonista, Bento, indo em direção ao acidente. Em seguida, pelo recurso do voice-over, a cena traz a voz do protagonista dizendo que nunca acreditou em destino, mas que bastaram dois anos para que sua vida virasse do avesso, ao mesmo tempo em que a câmera mostra-o em seu escritório de engenharia, em São Paulo. Na próxima cena, aparece um ensaio da banda Capital Inicial, no Rio de Janeiro, sendo produzido por Miguel e Dani, amigos e colegas de profissão. Ambos vão a São Paulo a trabalho e, por uma brincadeira de Dani, Miguel marca um encontro com Bento, cujo apelido é Dom. Eles foram colegas na faculdade de engenharia, embora Miguel não tenha concluído o curso. Em comparação com o estilo apresentado por Bento (cabelos curtos, roupas sociais, apartamento impecavelmente arrumado), o personagem Miguel é configurado por não ter concluído a faculdade de engenharia, trabalhar com mídia e usar roupa esportiva, que, em conjunto, aludem a um jeito mais desembaraçado e maleável de tratar com as situações que se apresentam.

Bento recebe um convite do amigo para ir ao estúdio onde estão fazendo testes com algumas modelos e lá encontra Ana, sua amiga de infância, a quem dera o apelido de Capitu. No momento em que a encontra, ele relembra o passado e, a partir daí, não consegue mais 
tirá-la de sua mente, buscando pretextos para encontrá-la, até mesmo no Rio de Janeiro, onde ela mora. Ao contrário do livro, que dedica grande parte do enredo a contar o enamoramento entre Bento e Capitu e o processo de conquista do aval da mãe de Bento para que pudesse casar-se em vez de ser padre, aqui o vínculo afetivo iniciado em tenra idade é recapitulado em flashback, rápida e resumidamente, enquanto que a aprovação da mãe do rapaz sai completamente da história, aludindo à diminuição das hierarquias familiares e ao afrouxamento dos vínculos de parentesco que caracterizam as relações familiares do final do século vinte. Em pouco tempo, ambos estão apaixonados e ele a pede em casamento. Ela hesita, mas aceita e vai morar com Bento em São Paulo. Essa é uma das divergências consideráveis de temperamento, os traços psicológicos, entre Ana e a Capitu, pois o personagem do romance não vacila em momento algum, mostra-se determinada em relação àquilo que deseja.

Miguel e Dani são os melhores amigos do casal. Algum tempo depois, Ana e Bento têm um filho, Joaquim; e, Bento, que já demonstrava indícios de ciúmes da esposa, começa a suspeitar da amizade entre Ana e Miguel, considerando que os dois possam ter algo além. Ao mesmo tempo, ele começa a pensar na possibilidade de Joaquim não ser seu filho. A intriga se agrava quando Miguel convida Ana para voltar a trabalhar, atuando em um filme que ele produzirá, diante do que Bento se mostra completamente contrariado.

Bento começa a agir de forma possessiva com a esposa, exigindo que escolha entre ele ou o trabalho dela: tal como a Capitu do livro, ela não lhe dá ouvidos. Os ciúmes e as desconfianças do rapaz aumentam, resultando em um exame de DNA, que Bento realiza contra a vontade de Ana, o que leva ao fim do casamento. Como já o advertira, ela sai de casa com o filho e deixa uma carta de despedida sob o resultado do exame de DNA ainda fechado. Bento recebe, então, uma ligação com a qual fica sabendo que Ana e Joaquim sofreram um acidente de carro. Chegando ao local, ele é avisado de que a esposa falecera no acidente e seu filho estava bem. Bento volta para a casa com o filho e resolve dedicar a ele o amor que ainda sente pela esposa. Queima o exame de DNA, concluindo que perder Joaquim seria como perder Ana duas vezes. O exame, nesse caso, é uma atualização, pois a fins do século XX seria inverossímil propor a impossibilidade de constatar a existência do vínculo sanguíneo entre os dois.

O deslocamento temporal da história a transfere do século XIX para o século XXI, ou finais do século XX, o que acarreta, por exemplo, mudanças na maneira como os personagens 
são distribuídos. O romance é constituído de vários personagens, como José Dias, Tio Cosme e prima Justina, que vivem como agregados na casa de Bentinho; a viúva Dona Glória, mãe de Bento; o padre Cabral, amigo da família; os pais de Capitu; Escobar, amigo do casal; Sancha, amiga do casal; Ezequiel, filho de Capitu e Bento, e outros personagens secundários que aparecem ao longo do romance. $\mathrm{O}$ elenco do filme se restringe ao casal protagonista, juntamente com os amigos Miguel e Dani; Heloísa, a namorada de Bento no começo do filme; além de Joaquim, filho de Ana e Bento, e outros poucos personagens figurantes.

Da família alargada à família nuclear, composta de pai, mãe e filho, que vivem em um apartamento/edifício, onde não aparece nenhum contato com vizinhos e a mãe do protagonista é mencionada em um telefonema (contatos mediados). Essa alteração se relaciona, ademais, com os tempos de duração de um e de outro tipo de produto: enquanto que o livro conta com mais de duzentas páginas, em que são apresentados vários personagens e circunstâncias, o filme enxuga a história e focaliza na trama conduzida pelos personagens centrais. Adicionalmente, como diferença entre os suportes, pode-se dizer que enquanto os personagens entram e saem do livro sem adquirir necessariamente espaço dentro da história, no filme, cada um que entra em cena se destaca, produz um efeito de encarnação, como diz Subouraud (2010), o que solicita, muitas vezes, o enxugamento dos elementos introduzidos em uma hora e meia de encenação.

Como manifestação das mudanças culturais, os papéis sociais desempenhados pelos personagens são adequados ao que é mais corriqueiro em cada época. Enquanto a Capitu do romance era exclusivamente dona de casa e mãe, Ana tinha uma carreira como modelo e atriz antes de se casar e não pretendia abandoná-la após o casamento. Bento é engenheiro, afinando-se com a São Paulo industrial e cosmopolita, enquanto Bentinho desiste do celibato para ser advogado, formação acadêmica típica de seu setor social na época em que se passa a história contada pelo romance. Miguel possui uma produtora, enquanto o Escobar do romance era comerciante, ao passo que Sancha fazia o mesmo que Capitu, e Dani trabalha com Miguel na produtora. Bentinho e Escobar tornaram-se amigos no seminário, que acabou sendo abandonado por ambos; já Bento e Miguel conheceram-se na faculdade de engenharia, que só Bento terminou.

Outro deslocamento no âmbito cultural é que, no livro, era Capitu quem tomava a iniciativa em relação ao romance com Bentinho, ou pelo menos era isso que ele sentia: que ela se insinuava, o enfeitiçava, e não que ele se sentia enfeitiçado ou fascinado por ela. Em Dom, 
quem insiste com a moça e toma as iniciativas principais no relacionamento é Bento. Como na época do romance a mulher era condicionada quase que exclusivamente ao casamento, por esse viés é possível situar a percepção de Bentinho acerca da insistência de Capitu em investir no romance com ele, bem como a sua insegurança sobre os reais sentimentos da jovem: ele conjecturava que ela poderia estar com ele pelo fato de que precisava casar-se. Se no romance, o narrador-protagonista sugere em alguns momentos que tem dúvidas quanto aos reais interesses de Capitu, também pela diferença de status social e financeira entre as duas famílias; no filme, o que gera insegurança em Bento é o fato de Ana querer ter uma carreira e não desejar abdicar de todos os seus outros interesses para dedicar-se unicamente a ele. $\mathrm{O}$ espírito livre da Capitu do romance, de mulher forte e determinada, que não se dobra e tampouco se restringe devido às inseguranças de Bentinho, é resgatado na obra derivada na composição da personagem Ana, que almeja continuar a ter uma vida profissional e deseja olhar em volta, estar com outras pessoas.

Além dos referidos deslocamentos, temporais, culturais e geográficos, temos outras modificações do filme em relação ao romance, principalmente no que tange ao desfecho; tais como: a maneira encontrada por Góes para manter o suspense sobre a paternidade do filho do casal, que é o exame de DNA sendo queimado por Bento. O fato de Ana não ter aberto o exame, antes de deixá-lo aos cuidados do marido, depõe a favor de sua inocência, fazendo com que sua culpa seja posta em dúvida, como no romance, que não resolve essa questão.

Outro aspecto relevante é que o Bento de Góes acaba sendo mais resignado que o de Machado, pois enquanto Dom prefere ficar com a única coisa que lhe restou da tragédia em que resultou seu amor por Ana, - seu filho, Joaquim, a quem ele termina dedicando todo o seu amor -, Dom Casmurro, com a reticência indicada no próprio apelido, nunca consegue aceitar o filho que ele acreditava não ser seu. Muito pelo contrário, não só recebe com indiferença a notícia da morte de Ezequiel, como parece sentir-se aliviado com ela, tal como se pode ver no capítulo do livro, intitulado Não houve lepra, no qual, sabendo da morte do filho nas mediações de Jerusalém e, recebendo a conta das despesas com o sepulto deste, ele disse que pagaria o triplo para não mais tornar a vê-lo (ASSIS, 1997, p. 236).

Podemos ainda acrescentar que o Bento de Góes chega a ir atrás de Ana no apartamento, parecendo ter acordado do transe de seu ciúme, chamando alegremente por ela, quando recebe a notícia de sua morte. Já o Bentinho machadiano conclui seu livro dizendo ao leitor que está, agora, certo de que foi traído: 
E bem, qualquer que seja a solução, uma cousa fica, e é a suma das sumas, ou o resto dos restos, a saber, que a minha primeira amiga e o meu maior amigo, tão extremosos ambos e tão queridos também, quis o destino que acabassem juntando-se e enganando-me... A terra lhes seja leve! Vamos à "História dos Subúrbios" (Ibidem, p. 217).

\section{Considerações finais}

Além do título, que indica, explicitamente e desde o início, a existência de um vínculo com a obra-fonte, o filme de Góes pega do romance de Machado de Assis a história, ou seja: dois jovens, que se conhecem desde a infância, descobrem-se enamorados e casam-se. Ele tem ciúme e não tem certeza de que seu amor seja realmente correspondido. A jovem engravida, ele atribui a paternidade da criança ao seu melhor amigo, o casamento desfaz-se, e ele se sente infeliz. Enquanto transfere esses elementos da obra-fonte, o filme adapta, no sentido proposto por McFarlane, o enredo, ajustando-o à linguagem, ao suporte, e adequandoo ao receptor de sua época, no sentido de apresentar personagens com características verossímeis no seu contexto de produção e de realocação.

As alterações no enredo decorrem, em primeiro lugar, do deslocamento temporal da obra, cuja história se passa um século depois daquela em que o romance foi escrito, o que demanda uma adequação das questões propostas ao contexto histórico-social de princípios do século XXI. Assim, em lugar de haver um advogado, um comerciante e mulheres confinadas nas esferas familiares e domésticas do mundo social, temos um engenheiro, uma modelo/atriz e um casal de amigos que trabalha com produção de bens culturais. No filme, a força e a determinação de Capitu são traduzidas por sua obstinação em continuar a trabalhar fora de casa depois de casada, o que caracteriza uma situação corriqueira e uma problemática contemporânea entre a população feminina adulta.

As alterações identificadas se derivam, em segundo lugar, da opção por começar a narrativa pelo reencontro de Bento e Ana, já adultos. Nesse sentido, toda primeira parte do livro é suprimida, que começa com os dois ainda crianças e que fala de como se descobriram enamorados, bem como dos obstáculos que tiveram que superar para que pudessem casar-se. Tendo em vista que o filme subtrai dois terços do livro, na qual constam as intrigas de José Dias e a relação de Bentinho com a sua mãe — o filho único de uma viúva de posses deixa de fora o que, de certa forma, poderia servir para explicar os ciúmes e a insegurança que levam à ruptura definitiva do relacionamento entre os dois. O receptor atual não poderá 
encontrar aí a explicação do ocorrido: se não conhece a obra de partida, deverá ater-se ao que este texto lhe dá, interpretando a atitude de Bento como: incapacidade de compartilhar, machismo, obsessão ou atribuir-lhe à sua percepção aguçada e acertada do seu em torno.

Embora tenha sido feita a redução do tempo diegético da trama, o filme, por outro lado, dilata a parte final do livro e concentra-se quase que por completo no desenvolvimento da etapa adulta da história, opção que também se verifica em outra adaptação para o audiovisual de Dom Casmurro, o filme Capitu, de 1968. À diferença desse último, no entanto, há em Dom o deslocamento de tempo histórico, o que gera, como dito, outras demandas de atualização.

Um desafio na adequação com o qual se deparou o cineasta e que é imprescindível para a reproposição do conflito central da história foi a reconstituição dos "olhos de ressaca", um dos elementos desencadeadores da dúvida de Bento, e da ambiguidade e da malícia, atribuída por ele ao comportamento de Ana e Miguel. À diferença do Bentinho do livro, que narra os fatos segundo o seu ponto de vista - e que, por isso, o leitor não tem como saber se assim aconteceram ou se ele atribui ao que vê um significado que não tem - o filme encena as situações e, adicionalmente, usa o recurso do voice-over para expor as dúvidas de Bento. Há, aqui, uma discrepância na forma de expressar de cada linguagem, pois o cinema dá a ver e deve encenar a interioridade dos personagens, enquanto que no livro o leitor segue e reconstitui o que lhe é dito e tem maior acesso aos traços psicológicos e às idiossincrasias de cada qual.

Por último, se o Bentinho de Dom Casmurro opta por permanecer em sua "casmurrice" até o final de seus dias, o Bento de Góes dá sinais de possuir o "dom” de perdoar ou ao menos de conviver, da forma que julga possível, com aquilo que lhe restou. Ainda assim, o filme segue a ruptura definitiva, entre os personagens, proposta pela obrafonte, e mesmo quando Bento tenha se mostrado arrependido, a trama não lhe deixa escolha e faz com que a sua desconfiança tenha consequências irreversíveis, por meio do acidente, seguido da morte de Ana.

Identifica-se, nesse caso, a transposição entre lógicas de produção e consumo diversas, pois o texto derivado aproveita o anterior e o repropõe desde os formatos industriais da cultura midiática, e levando em consideração as expectativas do público na recomposição temática do texto-fonte. Para tanto, enxuga aspectos da história, focalizando na última parte 
do romance, e recompõe o final, que passa a ser marcado pela superação dos problemas e pelo compromisso perseverante com a felicidade.

\section{Referências}

ASSIS, Machado. Dom Casmurro. São Paulo: Globo, 1997.

CLÜVER, Claus. Estudos interartes: conceitos, termos, objetivos. In: Literatura e sociedade. Revista de Teoria Literária e Literatura Comparada, USP. N 2, 1997.

DINIZ, Taïs Flores Nogueira. Literatura e cinema: tradução, hipertextualidade, reciclagem. Belo Horizonte: Faculdade de Letras da UFMG, 2005.

GÓES, Moacyr (direção). Dom. Diler \& Associados / Warner Bros, 2003. (91min.).

GUIMARÃES, Helio. O romance do século XIX na televisão: observações sobre a adaptação de Os Maias. In: PALLEGRINI, Tânia et al. (orgs). Literatura, cinema, Televisão. 2. ed. São Paulo: SENAC São Paulo: Instituto Itaú Cultural, 2003. p. 91-114.

HUTCHEON, Linda. Uma teoria da adaptação. Tradução de André Cechinel. Florianópolis: Ed. da UFSC, 2011.

JAUSS, Hans Robert. Esperienza estetica ed ermeneutica letteraria. Bologna: Il Mulino, 1987. Vol. 1.

JENSEN, Klaus Bruhn. La Comunicación en contextos. In: La comunicación y los medios. México: Fondo de Cultura Económica, 2014.

MARTÍN BARBERO, Jesús. Ofício de cartógrafo. Santiago, Chile: Fondo de Cultura Económica, 2003.

MCFARLANE, Brian. Backgrounds, issues, and a new agenda. In: Novel to film: an introduction to the theory of adaptation. Oxford: clarendon press - Oxford University Press, 1996.

NAGAMINI, Eliane. Literatura, televisão, escola: estratégias para leitura de adaptações. São Paulo: Cortez, 2004.

SANDERS, Julie. Adaptation and appropriation. New York, USA, 2008.

SARACENI, Paulo Cezar. (Direção) Capitu. Imago, 1968. (143 min.).

STAM, Robert. A Literatura através do cinema: realismo, magia e a arte da adaptação. Tradução de Marie Kremer e Glaucia Renate. Belo Horizonte: Editora UFMG, 2008. 
Teoria e prática da adaptação: da fidelidade à intertextualidade. Ilha do Desterro. $\mathrm{n}$. 51, Florianópolis, jul./dez. 2006, p. 19-53.

SUBOURAUD, Frédéric. La adaptación. El cine necesita historias. Tradução de Alica Capel Tatjer. Madrid: Paidós, 2010.

\title{
The novel to film: transfer and translation in the Dom adaptation
}

\begin{abstract}
This paper aims to discuss about the adaptation of literature for audiovisual works, from aspects of transfer and translation of elements of a media to another, considering works with a diversity of languages and shifting of historical and social context of production in the reproposition theme. To this end, we analyze the film Dom, by Moacyr Góes, produced in 2003, about a century after the writing of the novel Dom Casmurro, by Machado de Assis, in which it was inspired. We identify, in this case, the changes related to actions, events and characters of the composition of the narrative in the construction of a derivative work. Identifies, then, the transposition between logics of production and various consumption, because the derivative text builds on the previous and the reproposes from industrial formats of media culture, and taking into account the expectations of the public in thematic recomposition of the source text. Therefore, wipes aspects of the story, focusing on the last part of the novel, and recompose the end, which is now marked by overcoming the problems and the persevering commitment to happiness.
\end{abstract}

Keywords: Audiovisual. Translation. Narrative

Recebido em: 30 de agosto de 2016.

Aprovado em: 05 de dezembro de 2016. 